\title{
QUALITATIVE AND QUANTITATIVE PHYTOCHEMICAL ANALYSIS AND DPPH RADICAL SCAVENGING ACTIVITY OF DIFFERENT EXTRACTS OF FLOWER OF BAUHINIA ACUMINATA LINN
}

\author{
SREEJA SANJEEV, REGI RAPHAEL $\mathrm{K}$. \\ Department of Botany, St. Mary's College, Thrissur \\ Email: puthumanasandeep@gmail.com
}

Received: 20 Aug 2017, Revised and Accepted: 13 Oct 2017

\begin{abstract}
Objective: Bauhinia acuminate L (Fabaceae) is a species of flowering shrub native to tropical southeastern Asia. The flower of B. acuminata are used against various skin diseases, worms, tumours and diabetes. The Indian vaiydas recommended a remedy to treat severe biliousness.

The qualitative and quantitative estimation of phytochemical constituents in various extracts and the antioxidant potential of the flower of Bauhinia acuminata were evaluated.
\end{abstract}

Methods: All the analysis was done based on standard protocols.

Results: The phytochemical screening reveals the presence of various primary and secondary metabolites like sugar, carbohydrate, amino acid, fat, quinone, steroids, phenol, saponin, alkaloids, and acid content. In quantitative analysis, the important secondary metabolites such as alkaloids and phenolic compounds were estimated in all the extracts.

The ethanol and chloroform extract produced significant antioxidant properties in a dose-dependent manner. DPPH free radical scavenging assay of ethanol and chloroform extracts of flower exhibited IC 50 values of $24.44 \pm 1.201 \mu \mathrm{g} / \mathrm{ml}$ and $196.68 \pm 0.456 \mu \mathrm{g} / \mathrm{ml} \mathrm{respectively.} \mathrm{At} 1000 \mu \mathrm{g} / \mathrm{ml}$ concentration both extracts shows maximum radical scavenging activity (98.97\% and $85.67 \%)$.

Conclusion: The findings of this study indicate that this plant is medicinal with the prominent antioxidant property.

Keywords: B. acuminata, Photochemicals, Antioxidant, DPPH radical scavenging

(c) 2017 The Authors. Published by Innovare Academic Sciences Pvt Ltd. This is an open-access article under the CC BY license (http://creativecommons.org/licenses/by/4.0/) DOI: http://dx.doi.org/10.22159/ijcpr.2017v9i6.23423

\section{INTRODUCTION}

Nature has provided a complete storehouse of remedies to cure all ailments of humankind [1]. Traditional medicine use is a common practice in developed and developing countries at the primary healthcare level [2]. Herbal medicines are prepared from various plant parts like leaves, stem, roots, barks and seeds, which usually contain many bioactive compounds and used primarily for treating mild or chronic ailments. Due to the increasing demand in the field of herbal medicines, it has become necessary and pertinent to probe into the area of systematic knowledge about herbal drugs. There is a need for the application of this knowledge in authentication, detailed study and practical utilization of crude drugs [3].

Bauhinia acuminate L, belongs to the family Fabaceaeis a species of flowering shrub native to tropical southeastern Asia. In Malaysia and Indonesia the plant is used in the treatment of common cold and cough [4]. While in India the leaves and bark of this plant are used for treating asthma [5]. Moreover, the leaf of B. acuminata is used to treat bladder stone, venereal diseases, leprosy, asthma and digestive diseases. Different part of this plant such as bark, leaves, stem, flowers and roots have been used in traditional medicine [6]. The plant was also used as febrifuge, vermifuge, anticonvulsant and against chicken pox, guinea worm and black quarter [7-8]. Though different parts of this plant were reported to possess good medicinal properties [9], there is no published study particularly on the phytochemical and antioxidant activity of $B$. acuminata flower. Hence, the focus of this study was to investigate qualitative and quantitative phytochemical analysis and antioxidant activities in flower extracts of $B$. acuminata.

\section{MATERIALS AND METHODS}

\section{Collection and identification of plant materials}

The plant B. acuminata were collected from Edapal, Malappuram District of Kerala, India. Taxonomic identification with Flora of Presidency of Madras by JS Gamble [10].

\section{Preparation of extracts}

Flower of the plant was shade dried for several days. The dried plant material was ground to a coarse powder and $50 \mathrm{gm}$ of the powdered plant material was soaked in solvents of increasing polarity starting petroleum ether, chloroform, ethyl acetate, ethanol and distilled water (1:5) for $72 \mathrm{~h}$ [11]. The solvent was then removed by rotary evaporation. Each residue was weighed and the yield percentage [12] was determined. The dried extract was stored in the refrigerator for further studies.

\section{Qualitative phytochemical analysis}

The phytochemical screening of the plant extract in various solvents was performed by using standard protocol given by Harbone [13].

\section{Quantitaive phytochemical analysis}

\section{Determination of total phenolic content}

Total phenolic content analysis was performed by the method of Malick et al. [14]. Dissolve the test extract in the concentration of 1 $\mathrm{mg} / 1 \mathrm{ml}$ and make up this test solution up to $3 \mathrm{ml}$ with distilled water $0.5 \mathrm{ml}$ Folin-Ciocalteau reagent and $2 \mathrm{ml}$ of $20 \% \mathrm{Na}_{2} \mathrm{CO}_{3}$ were respectively added. The samples were thereafter incubated in boiling water bath exactly for one minute. The absorbance was measured by using spectrophotometer at $650 \mathrm{~nm}$ against reagent as blank.

A standard calibration plot was generated at $650 \mathrm{~nm}$ using known concentrations of catechol. The concentrations of phenols in the test samples were calculated from the calibration plot and expressed as catechol equivalent of phenol/g of sample. Each extract was assayed in triplicates.

Determination of total alkaloid content [15].

The plant extract $(1 \mathrm{mg} / 1 \mathrm{ml})$ was dissolved in $2 \mathrm{~N} \mathrm{HCl}$ and then filtered. $1 \mathrm{ml}$ of this solution was transferred to a separating test 
tube, and then $5 \mathrm{ml}$ of Bromocresol green solution along with $5 \mathrm{ml}$ of phosphate buffer with neutral PH were added. The mixture was shaken and the complex formed was extracted with chloroform by vigorous shaking. The extract was collected in a $10 \mathrm{ml}$ volumetric flask and diluted with chloroform. Now, the absorbance of the complex in chloroform was measured at $470 \mathrm{~nm}$ against the blank prepared as above but without atropine. The whole experiment was conducted in triplicates.

A standard calibration plot was generated at $470 \mathrm{~nm}$ using known concentrations of atropine. The concentrations of alkaloids in the test samples were calculated from the calibration plot and expressed as atropine equivalent of alkaloid/g of sample.

\section{Antioxidant property screening \\ DPPH radical scavenging assay}

The free radical scavenging activity of the plant extracts assessed based on the radical scavenging effect of the stable 1, 1-diphenyl-2picrylhydrazyl (DPPH), by a method given by Braca et al., [16]. The diluted test solutions $(10 \mu \mathrm{g} / \mathrm{ml}-1000 \mu \mathrm{g} / \mathrm{ml}$ concentration $)$ and $6.34 \mu \mathrm{M}$ solution of DPPH were prepared in methanol, and $100 \mu \mathrm{l}$ test, along with $100 \mu \mathrm{LPPH}$ solution and $800 \mu \mathrm{l}$ of methanol was taken in a test tube and mixed well. These solution mixtures were kept in dark for 20 min and optical density was measured at $517 \mathrm{~nm}$ using Cecil-Elect Spectrophotometer. Methanol $(900 \mu \mathrm{l})$ with DPPH solution $(6.34 \mu \mathrm{M}, 100 \mu \mathrm{l})$ taken as control and methanol as blank. The optical density recorded and percentage of inhibition calculated using the formula given below [17].

Percentage (\%) inhibition of DPPH activity = A-B $/ \mathrm{A} \times 100$
Where $\mathrm{A}=$ optical density of the control and $\mathrm{B}=$ optical density of the sample.

Sample concentration providing $50 \%$ inhibition (IC50) was calculated from the graph plotting inhibition percentage against extract concentration.

\section{Statistical analysis}

All the analysis were performed in triplicate and the results were statistically analyzed and expressed as mean $(n=3) \pm s t a n d a r d$ deviation.

\section{RESULTS AND DISCUSSION}

\section{Yield of extract}

Comparatively, flower ethanol extract exhibited higher extraction yield. The extraction ability of different solvents for recovering extractable components from flower followed the order: ethanol $(2.00 \mathrm{~g})>$ chloroform $(1.26 \mathrm{~g})>$ petroleum ether $(1.13 \mathrm{~g})>$ ethyl acetate $(1.10 \mathrm{~g})>$ distilled water $(1.02 \mathrm{~g})$. The variation in yield may be due to the polarity of the solvents used in the extraction process.

\section{Preliminary phytochemical screening}

The phytochemical analysis is of paramount importance in identifying a new source of therapeutically and industrially valuable compounds having medicinal plants have been chemically investigated [18]. The preliminary Phytochemical screening showed the presence of primary and secondary metabolites like sugar, carbohydrate, amino acid, fat, quinone, steroids, phenol, saponin, alkaloids, and acid content (table 1).

Table 1: Phytochemical screening of flower of $B$. acuminata in different solvents

\begin{tabular}{|c|c|c|c|c|c|c|}
\hline $\begin{array}{l}\text { Primary and secondary } \\
\text { metabolites }\end{array}$ & Test/Reagent & Petroleum ether & chloroform & Ethyl acetate & Ethanol & Distilled water \\
\hline Carbohydrate & Molisch's reagent & + & + & + & + & + \\
\hline Starch & Iodine test & - & - & - & - & - \\
\hline Sugar & Benedict's test & - & + & + & + & + \\
\hline Ketose & Seliwanoff"s test & - & - & - & - & - \\
\hline Proteins & Biuret test & - & - & - & - & - \\
\hline Amino acid & Ninhydrin test & + & - & - & - & - \\
\hline Fat & Filter paper test & + & + & + & + & + \\
\hline Quinone & $\mathrm{H}_{2} \mathrm{SO}_{4}$ test & - & - & - & - & + \\
\hline Cardiac glycoside & Kellar-killani test & - & - & - & - & - \\
\hline Steroids & Salkowski test & - & - & + & - & - \\
\hline Flavonoids & Fluorescent test & - & - & - & - & - \\
\hline Phenols & Folin test & + & + & + & + & + \\
\hline Saponins & Foam test & - & - & - & - & + \\
\hline Alkaloids & Dragendroff's reagent & + & + & + & + & + \\
\hline Tannin & $\mathrm{FeCl}_{3}$ test & - & - & - & - & - \\
\hline Terpenoids & Salkowski test & - & - & - & - & - \\
\hline Acid & $\mathrm{NaHCO}_{3}$ test & + & - & + & + & + \\
\hline
\end{tabular}

+indicates the presence of metabolite,-indicate the absence of metabolite

\section{Quantitative estimation of phenol and alkaloid compounds}

Secondary metabolites analysis is necessary for extraction, purification, separation, crystallization, identification of various phytocompounds. Calibration curve of catechol and atropine is given in fig. 1 and fig. 2. Phenol and alkaloid are present in all the samples extracted by five different solvents. The total phenol content was highest with $(1.26 \pm 0.01)$ catechol/g in ethanol extract followed by $(1.17 \pm 0.02)$ catechol/g of ethyl acetate extract. Phenols are antiseptic and reduce inflammation when taken internally. These bioactive agents have an irritant effect when applied to the skin. Above of all, phenols have a high affinity to chelate metals and scavenge the free radicals in cells [19]. Polyphenols act as antioxidants, which protect cells and body chemicals against damage, caused by free radicals and reactive atoms that contribute to tissue damage in the body. It has been reported that these compounds deactivate the substances that promote the growth of tumours [20]. Consumption of diets rich in plant polyphenols offers protection against the development of cancer, cardiovascular diseases, diabetes, osteoporosis and neurodegenerative diseases.

Alkaloids protect against chronic diseases [21] and earlier recorded that bitter leaf contains an alkaloid that is capable of reducing headaches associated with hypertension. Alkaloids are a diverse group of secondary metabolites found to have antimicrobial activity by inhibiting DNA topoisomerase [22]. Alkaloid constituents in flower showed that the chloroform extract had higher amounts $(0.72 \pm 0.03)$ atropine/g of the extract followed by $(0.66 \pm 0.02)$ atropine/g of the ethyl acetate extract. The results are tabulated in table 2 .

\section{Antioxidant property of flower}

Antioxidant compounds may function as free radical scavengers, initiator of the complexes of pro-oxidant metals, reducing agents and quenchers of singlet oxygen formation [23]. Therefore, the importance of the search for natural antioxidants has increased in the recent years so many researchers focused the same [24]. 


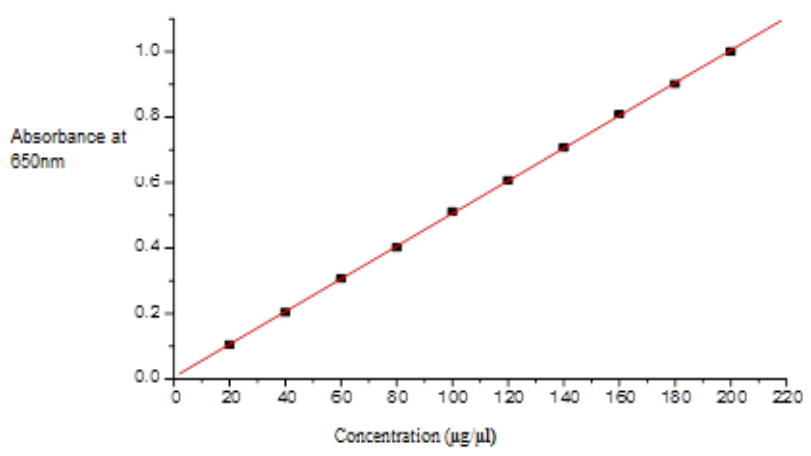

Fig. 1: Catechol calibration curve

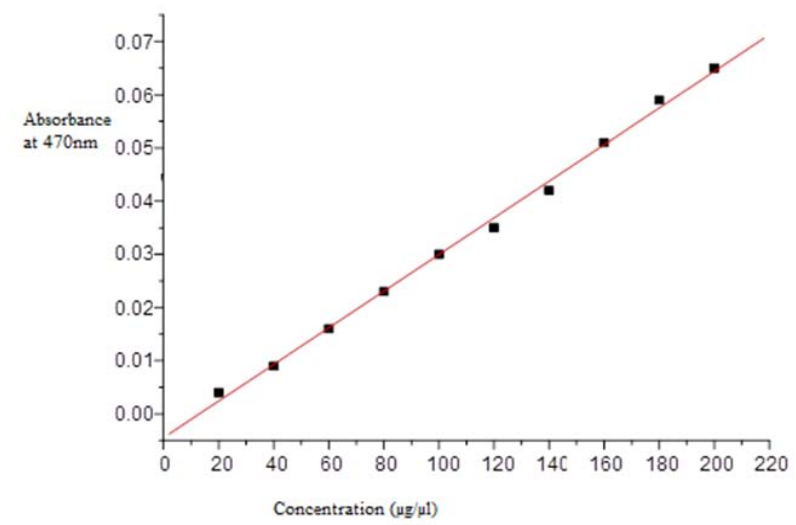

Fig. 2: Atropine calibration curve

Table 2: Quantitative estimation of total phenol and alkaloid content of different extracts

\begin{tabular}{lll}
\hline Extracts & Phenol (Catechol/gm) & Alkaloid (Atropine/gm) \\
\hline Petroleum ether & $0.13 \pm 0.03$ & $0.35 \pm 0.01$ \\
Chloroform & $1.05 \pm 0.01$ & $0.72 \pm 0.03$ \\
Ethyl acetate & $1.17 \pm 0.02$ & $0.66 \pm 0.02$ \\
Ethanol & $1.26 \pm 0.01$ & $0.41 \pm 0.03$ \\
Distilled water & $0.92 \pm 0.01$ & $0.37 \pm 0.02$ \\
\hline
\end{tabular}

Values are means of three independent determinations \pm standard deviations (SD).

\section{DPPH radical scavenging assay}

Among the five different extracts, ethanol and chloroform extracts showed higher phenol and alkaloid contents respectively. Therefore the free radical scavenging potential of these two extracts tested by DPPH assay is given in the table 3. Reduction of the DPPH radicals was observed by a decrease in absorbance where a change in the color to yellow denotes quenching of the free radicals by the plant extracts. The analysis of the radical scavenging activity of the extracts increases with increase in concentration. Ethanol extract of the flower was found to have the most potent antioxidant property with $\mathrm{IC}_{50}$ value of $24.44 \pm 1.201 \mu \mathrm{g} / \mathrm{ml}$ than chloroform extract with $196.68 \pm 0.456 \mu \mathrm{g} / \mathrm{ml}$. The high activity of ethanol extract of the flower is generally attributed to the presence of alkaloids and phenols, as the majority of active antioxidant compounds are observed in these classes of phytochemical compounds. The secondary metabolites phenol and alkaloids which carry a major importance to increase an antioxidant potential. Information obtained from these studies can be used as markers in the identification and standardization of this plant as an herbal remedy and also towards monograph development of the plant.

Table 3: DPPH scavenging activities of extracts of flower (values represent mean $\pm S D, n=3$ )

\begin{tabular}{llll}
\hline S. No. & Concentration $(\boldsymbol{\mu g} / \mathbf{m l})$ & Percentage of inhibition & Chloroform \\
\cline { 2 - 4 } & & Ethanol & $15.52 \pm 0.898$ \\
1 & 10 & $45.20 \pm 0.644$ & $17.24 \pm 0.941$ \\
2 & 15 & $48.32 \pm 0.597$ & $25.59 \pm 0.716$ \\
3 & 25 & $55.42 \pm 1.325$ & $29.70 \pm 1.290$ \\
4 & 50 & $63.57 \pm 0.580$ & $31.56 \pm 1.087$ \\
5 & 75 & $76.68 \pm 1.154$ & $38.37 \pm 1.402$ \\
6 & 100 & $87.13 \pm 1.038$ & $59.17 \pm 0.691$ \\
7 & 250 & $95.20 \pm 0.689$ & $74.21 \pm 0.907$ \\
8 & 500 & $96.78 \pm 0.395$ & $81.35 \pm 1.026$ \\
9 & 750 & $97.79 \pm 0.358$ & $85.67 \pm 0.544$ \\
10 & 1000 & $98.97 \pm 0.740$ & $196.68 \pm 0.456$ \\
\end{tabular}




\section{CONCLUSION}

Phytochemical studies portray the presence of several biologically active secondary metabolites such as phenol and alkaloids in the bark of B. acuminata for the first time. The antioxidant efficacy of ethyl acetate extract is very high with $\mathrm{IC}_{50}$ value of $42.62 \pm 0.859$ $\mu \mathrm{g} / \mathrm{ml}$, indicates that this plant can have great scope for isolation and identification of important antioxidant molecules which can be formulated to make antioxidant dosage forms. Significant correlations were found between the antioxidant capacities and phenolic contents indicating that phenolic compounds are the major contributors to antioxidant capacity. On top of that, these natural antioxidants can have potential advantages among various diseases with oxidative stress. So, further study is necessary to get maximum benefit from this plant.

\section{CONFLICT OF INTERESTS}

\section{Declared none}

\section{REFERENCES}

1. Kokate CB, Purohit AP, Gokhale SB. Pharmacognosy. $18^{\text {th }}$ edition. Pune India: Nirali Publication; 2002.

2. Essawi T, Srour M. Screening of some Palestinian medicinal plants for antibacterial activity. J Ethnopharmacol 2000;70:343-9.

3. Kirikar KR, Basu BD. Indian medicinal plants. Vol. 1. Dehar Dun, India: International books Distributers; 1980.

4. Timothy Johnson. CRC ethnobotany desk reference, CRC Press: LLC Boca Taton; 1999. p. 110

5. Khare CP. Indian medicinal plants: an illustrated dictionary. Springer-Verlag Berlin; 2007. p. 85.

6. Reyad-Ul-Ferdous M, Azam MG, Hossain MD. Phytochemical screening, in vitro membrane stabilizing activities and thrombolytic activities of Lophopetalumjavanicum. Int J Pharm Sci Res 2014;5:350-0.

7. Fordin DG. History and concept of big plant genera. Taxon 2004;53:753-76.

8. Singh S, Singh SK, Yadav AA. Review on cassia speices; pharmacological, traditional and medicinal aspects in various countries. Am J Phytomed Clin Ther 2013;1:291-312.

9. Mohammad FK, Rabeya IS, Ridwan BR, Mohammad AR. Evaluation of cytotoxicity of beta vulgaris and membrane stabilizing activities. Biomed Pharmacol J 2014;17:99-101.
10. Gamble JS. Flora of presidency of Madras. Aldard and son publishing company Ltd; 2004.

11. Taleb-Contini SH, Salvador MJ, Balanco JMF, Albuquerque S, De Oliveria DCR. Antiprotozoal effect of crude extracts and flavonoids isolated from Chromolaena hirsute (Asteraceae). Phyto Res 2004;18:250-4.

12. Patil UH, Gaikwad DK. Phytochemical evaluation and bactericidal potential of Terminaliaarjuna stem bark. Int J Pharm Sci Res 2010;2:614-9.

13. Harbone JB. Phytochemical methods, a guide to modern techniques of plant analysis. India: Springer pvt Hd; 1998.

14. Malick EP, Singh MB. Plant enzymology and Hittoenzymology, Kalyani Publishers, New Delhi; 1980.

15. Fadhil S, Monsef H. Spectrophotometric determination of total alkaloids in Peganumharmala L. using Bromocresol green. Res ] Phytochem 2007;1:79-82.

16. Braca A, Sortino C, Politi M. Anti-oxidant activity of flavonoids from Licanialicaniaeflora. J Ethnopharmacol 2002;79:379-81.

17. Bors W, Saran M, Elstner EF. Screening for plant anti-oxidants. In: Linskens HF, Jackson JF. eds. Modern Methods of Plant AnalysisPlant Toxin Analysis-New Series, Berlin: Springer; 1992;13:277-95.

18. Ambasta SP, Ramachandran K, Kashyapa K, Chand R. Useful plants of India. Publication and information directorate. Council of Scientific and Industrial Research, New Delhi; 1986. p. 4337.

19. Michalak A. Phenolic compounds and their antioxidant activity in plant growing under heavy metal stress. Polish J Environ Studies 2006;15:523-30.

20. Rahaman Onike. Phytochemical Screening Tests and Medicinal Values of Plants Active Properties; 2010.

21. Ayitey Smith E, Addae Mensah I. Phytochemical, nutritional and medical properties of some leafy vegetables consumed by Edo people of Nigeria. W Afr J Pharmacol Drug Res 1977;4:7-8.

22. Bonjean K, De Pauw-Gillet MC, Defresne MP, Colson P, Houssier C, Dassonneville L, et al. The DNA intercalating alkaloid cryptolepine interferes with topoisomerase II and inhibits primarily DNA synthesis in B16 melanoma cells. J Ethnopharmacol 1998;69:241-6.

23. Andlauer W, Furst P. Antioxidative power of phytochemicals with special reference to cereals. Cereal Foods World 1998;43:356-9.

24. Jayaprakasha GK, Selvi T, Sakariah KK. Antibacterial and antioxidant activities of grape (Vitisvinifera) seed extract. Food Res Int 2003;36:117-22. 